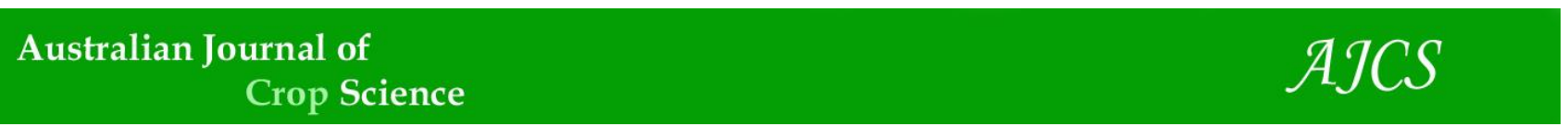

AJCS 14(09):1479-1486 (2020)

ISSN:1835-2707

doi: 10.21475/ajcs.20.14.09.p2603

\title{
Effect of brassinoesteroid hormone on oxidants activity of two contrasting cowpea cultivars subjected to saline stress
}

\author{
Rafael Sales Ohashi ${ }^{1}$, Glauco Andre dos Santos Nogueira ${ }^{1 *}$, Kerolém Prícila Sousa Cardoso ${ }^{2}$, Ana Ecídia de \\ Araújo Brito ${ }^{1}$, Liliane Corrêa Machado ${ }^{3}$, Jéssica Taynara da Silva Martins ${ }^{3}$, Thays Correa Costa ${ }^{3}$, Cândido \\ Ferreira de Oliveira Neto ${ }^{1}$, Ricardo Shigueru Okumura ${ }^{1}$, Júlia Karoline Rodrigues das Mercês ${ }^{1}$, Joaquim \\ Alves de Lima Junior ${ }^{1}$
}

\author{
${ }^{1}$ Universidade Federal Rural da Amazônia, Presidente Tancredo Neves Avenue, 2501, Belém city, Brazil \\ ${ }^{2}$ Universidade Estadual do Oeste do Paraná, Universitária Street, 1619, Cascavel city, Brazil \\ ${ }^{3}$ Universidade Federal de Santa Maria, Roraima avenue, 1000, Santa Maria city, Brazil
}

\section{*Corresponding author: glauand@yahoo.com.br}

\begin{abstract}
The aims of this study were to study the biochemical metabolism alterations generated by saline stress in two cowpea cultivars: BRS Guariba (moderately tolerant) and BR3 Tracuateua (sensitive), and to investigate the action of brassinosteroid in attenuation of oxidative stress. The results for water content and damage index in cell membranes were similar. Plants with 24-Epibrassinolide hormone maintained their water content satisfactory and without any membrane extravasation, whereas, for plants with salinity these variables decreased considerably. The results showed that salinity increased sodium $\left(\mathrm{Na}^{+}\right)$contents and reduced potassium $\left(\mathrm{K}^{+}\right)$content, which caused water increases allowing a higher dilution of sodium ions $\left(\mathrm{Na}^{+}\right)$, avoiding cellular toxicity. The antioxidant defense system of these plants (catalase, superoxide dismutase, ascorbate peroxidase, and guaiacol peroxidase) were activated mainly in characterization of salt stress, increasing their concentrations trying to avoid toxicity. The association of brassine and salinity caused reduction of lipid peroxidation characterized by malondialdehyde variable. These results corroborated the efficacy of the brassine hormone in cowpea plants under saline stress, characterizing as a plant plasticity.
\end{abstract}

Keywords: Brassinosteroids; Guariba; Physiological; Salinity stress; Tracuateua.

Abbreviations: BR_brassinosteroids; 24-EBL_24-Epibrassinolide; ROS_reactive oxygen species; CAT_catalase; SOD_superoxide dismutase; APX_ascorbate peroxidase; GPX_guaiacol peroxidase; MDA_malondialdehyde; DAS_days after sowing; RWC_relative water content; EL_electrolyte leakage.

\section{Introduction}

[Vigna unguiculata (L.) Walp], popularly known as cowpea, is one of the main food consumed by low-income populations living in Northern and Northeastern Brazil; it is mainly grown to produce dry or green beans (Medeiros et al., 2008).

Agricultural expansions throughout the Brazilian territory have been generating marginal regions susceptible to frequent droughts and salinized soils. It mainly happens in tropical regions, where adverse climatic conditions such as evapotranspiration and elevated temperatures prevail. These issues are often associated with inadequate water and soil management procedures, as well as to the use of high salt-content water, which significantly worsens the soilsalinization problem (Maia et al., 2010).

The excess of salts induces plant stress; thus, it is a limiting factor for the distribution and productivity of plant species (Yildirim et al., 2009; Qin et al., 2010). In addition, it decreases crop production and yield (Munns and Gilliham, 2015), besides enabling low osmotic potentials and high cation $\left(\mathrm{Na}^{+} ; \mathrm{Ca}^{2+} ; \mathrm{Mg}^{2+}\right.$, and $\left.\mathrm{K}^{+}\right)$and anion $\left(\mathrm{Cl}^{-}, \mathrm{SO}_{4}^{-}, \mathrm{HCO}_{3}\right.$, $\mathrm{CO}_{2}{ }^{-}$, and $\mathrm{NO}_{3}{ }^{-}$) concentrations (Toppa and Brambilla, 2011). Changes in plant metabolism resulting from $\mathrm{Na}^{+}$and $\mathrm{Cl}^{-}$ion accumulation in plant tissues lead to excessive production of reactive oxygen species (ROS), which can generate oxidative stress in plants Parvaiz and Satyawati (2008). Plants have an enzymatic system comprising enzymes such as catalase (CAT), superoxide dismutase (SOD), and ascorbate peroxidase (APX), which help mitigating damages caused by the excess of ROS observed in many cell compartments. This outcome is achieved by maintaining the balance between ROS production and elimination in order to keep cell homeostasis (Santos, 2015).

However, several hormones, among them brassinosteroids (BR), help modulating plant responses to abiotic stresses such as stress caused by salinity (Vázquez et al., 2019). This compound works as resistance inducer, besides enabling, inhibiting or changing physiological processes in plants subjected to stressful conditions (Sharma et al., 2007; Gonçalves et al., 2015), since is involved in regulation of reactive oxygen, carrying out metabolism of reactive oxygen species (ROS), especially in chloroplast, regulating the expression of certain antioxidant genes, promoting an increase in the activity of the main antioxidant enzymes, such as: superoxide dismutase, catalase, and ascorbate peroxidase (Coll et al., 2015; Ahanger et al., 2018). 
Fariduddin et al. (2014), observed that BRs influenced the transcription and/or translation of specific genes to activate the main antioxidant enzymes providing tolerance to plants in excess of salt conditions. According to Wang et al. (2016), 24-EBL promoted the detoxification of effects of $\mathrm{NaCl}$ induced stress, resulting in significant increases in net $\mathrm{CO}_{2}$ assimilation rate and efficiency in water use (Cheng et al., 2015). Thus, the exogenous application and/or the manipulation of content of endogenous BRs allows an alternative to increase crop yield in agricultural properties under conditions of salt stress.

Therefore, for testing the hipotesys that the action of 24Epibrassinolide attenuates the nocive effects of saline stress in cowpea plants, the aims of study were to investigate the role played by brassinosteroid mitigating the oxidative stress generated by saline stress in two cowpea cultivars.

\section{Results}

Relative water content and membrane damage index Brassinosteroid treatments ( $\mathrm{T} 2$ and $\mathrm{T} 3$ ) recorded the highest water content in the leaves (RWC) values. Plants subjected to brassinosteroid-free saline conditions (T4 and T5) showed decreased water content, which evidenced the negative effects of salt on these plants. This effect was stronger on Tracuateua cultivar, which showed statistically significant difference in water content in comparison to Guariba (Figure 1). Plants subjected to treatments based on correlations between salt and brassinosteroid doses recorded approximately $80 \%$ of RWC. There were statistically significant differences in RWC between cultivars subjected to $T 7, T 8$, and T9 treatments, whereas only plants subjected to different salt and brassinosteroid doses in T9 showed statistically significant differences (Figure 1).

Plants subjected to brassinosteroid treatments showed relatively-low MDI value (approximately $30 \%$ ); there was statistically significant differences in MDI between cultivars subjected to T2 and T3 (Figure 1). Plants under salt stress (T4 and T5) recorded approximately $60 \%$ and $80 \% \mathrm{MDI}$, respectively. Plants subjected to treatments based on the correlation between salt and brassinosteroid $(T 6, T 7, T 8$, and T9) did not show significant damages in cellular membranes (at cellular destructuring level) due to the effectiveness of the brassinosteroid hormone (Figure 1). Statistically significant differences in MDI were recorded only between cultivars subjected to the last two treatments.

Sodium in leaves and potassium contents

The increased saline concentration in solution led to significant $\mathrm{Na}^{+}$accumulation in leaves of both cultivars (Figure 2). Plants subjected to T4 $(50 \mathrm{mM} \mathrm{NaCl})$ and T5 (100 $\mathrm{mM} \mathrm{NaCl}$ ) recorded sodium concentrations 3 times higher than control; both treatments showed statistically significant difference in sodium concentration between cultivars.

The addition of 24-EBL to solution, as observed in T6 $(0.2 \mu \mathrm{M}$ $\mathrm{BR}+50 \mathrm{mM} \mathrm{NaCl}$ ), led to significant reduction in sodium concentrations in comparison to T4 and T5, which did not have BR. However, if one takes into consideration the high sodium concentrations in solution, the treatment presenting the best response was the one with highest 24-EBL concentration, T9 $(0.4 \mu \mathrm{M} \mathrm{BR}+100 \mathrm{mM} \mathrm{NaCl})$.

Potassium $\left(\mathrm{K}^{+}\right)$contents were strongly affected by saline treatment: plant subjected to T4 (with $50 \mathrm{mM} \mathrm{NaCl}$ concentration) recorded approximately $50 \%$ potassium content, whereas plants subjected to T5 (with $100 \mathrm{mM} \mathrm{NaCl}$ concentration) recorded more expressive potassium content in comparison to the control (Figure 6).
However, plants subjected to treatments associated with 24$\mathrm{EBL}$ recorded less expressive reduction in $\mathrm{K}^{+}$concentrations than $\mathrm{T} 4$ and $\mathrm{T} 5$, which increased $\mathrm{K}^{+}$contents in plants. If one takes into consideration the BR doses used in treatments, the highest $\mathrm{K}^{+}$concentration in leaves was recorded when $0.4 \mu \mathrm{M}$ BR concentration was adopted in T8 and T9, although there was no statistically significant variation between cultivars.

The effect of sodium-potassium ratio in cowpea plants

The $\mathrm{Na}^{+} / \mathrm{K}^{+}$ratio was strongly reduced by saline treatments, with emphasis on T4 $(50 \mathrm{mM} \mathrm{NaCl})$ and T5 $(100 \mathrm{mM} \mathrm{NaCl})$ (Figure 7). T4 recorded $90 \%$ reduction in the $\mathrm{Na}^{+} / \mathrm{K}^{+}$ratio, whereas $\mathrm{T} 5$ recorded $95 \%$ reduction in it, in comparison to the control. The 24-EBL addition to the treatments enabled seeing slight increase in $\mathrm{Na}^{+} / \mathrm{K}^{+}$ratio, mainly in plants subjected to T8 $(0.4 \mu \mathrm{M} \mathrm{BR}+50 \mathrm{mM} \mathrm{NaCl})$, which differed from other treatments in both cowpea cultivars. There was no significant variation in $\mathrm{Na}^{+} / \mathrm{K}^{+}$ratio between BR3 Tracuateua and BRS Guariba cultivars, at $5 \%$ probability level.

The decreased sodium concentrations after 24-EBL application may have resulted from reduced $\mathrm{Na}^{+}$contents in cell tissues, from the possible dilution of toxic salts, since the hormone increased the water content in the leaves (RWC); or from the increased accumulation, or synthesis, of compatible solutes in the plant, as reported in study.

Total soluble protein content

The soluble protein levels decreased at saline concentration $100 \mathrm{mM}$ : BR3 Tracuateua and BRS Guariba cultivars recorded $66 \%$ and $77 \%$ soluble protein decrease, respectively, in comparison to control.

The plants cultivated with brassino did not present significant increases of proteins, but when there was interaction of the $B R$ in plants with salinity even if superficial, there was an increase in concentrations of proteins soluble mainly in Guariba (T6 and T7). Thus, brassinosteroid treatments were capable of partially reversing the effects of saline stress on plants by increasing protein concentrations in both cultivars. Surprisingly, the highest BR concentration $(0.4 \mu \mathrm{M})$ did not present the best result in inducing the synthesis, or lower degradation, of proteins in both analyzed cultivars (Figure 6).

Activities of antioxidant enzymes in plants under salt stress Superoxide dismutase: Based on evaluation of antioxidative enzyme activity, SOD showed increased activity in treatments with $\mathrm{NaCl}$ and $\mathrm{EBL}$ (Figure $5 \mathrm{~A}$ ). SOD activity recorded values 3.72 and 4.87 times higher for cultivar BRS Guariba in T4 and T5 (50 and $100 \mathrm{mM} \mathrm{NaCl}$ ), respectively, whereas BR3 Tracuateua cultivar recorded values 2.59 and 3.16 times higher in T4 and T5, respectively, than the ones recorded for the control treatment (T1).

There was decreased SOD activity after 24-EBL addition to solution in comparison to T4 and T5; however, such activity remained high in comparison to the control. This outcome stood out in T9 $(0.4 \mathrm{BR}+100 \mathrm{mM} \mathrm{NaCl})$; there was no statistically significant difference between cultivars, the only difference was recorded between treatments at $5 \%$ significance level. T2 and T3 treatments, which only showed 0.2 and $0.4 \mu \mathrm{M}$ BR concentrations, respectively, did not present statistically significant difference in comparison to control.

Catalase: There was low catalase production in control and brassinosteroid treatments ( $\mathrm{T} 1, \mathrm{~T} 2$ and $\mathrm{T} 3$ ) because cultivars subjected to these treatments did not present metabolic dysfunctions (Figure 5B). The same outcome was not observed in plants subjected to T4 and T5 treatments, since 
only received salt doses and showed significant catalase production.

Plants subjected to treatments based on combination between brassinosteroid and salt doses did not present significantly increased catalase concentrations because the brassinosteroid (attenuator) blocked the deleterious effect of $\mathrm{Na}^{+}$and $\mathrm{Cl}^{-}$ions. Tracuateua cultivar recorded catalase accumulation among cultivars that have best adapted to saline condition. This outcome evidenced that these plants activated their defense systems, which enabled nitrogen peroxide $\mathrm{H}_{2} \mathrm{O}_{2}$ (reactive species largely produced under this stress condition) dismutation into water $\left(\mathrm{H}_{2} \mathrm{O}\right)$ and oxygen $\left(\mathrm{O}_{2}\right)$.

Ascorbate peroxidase: The highest APX concentrations were found in salt-stressed plants (T4 and T5), There were statistically significant differences in APX concentrations between cultivars in all treatments. However, cultivating Tracuateua was the most efficient in producing APX. The brassinosteroid dose presenting the best result was the one in $\mathrm{T7}(0.2 \mu \mathrm{M} \mathrm{BR}+100 \mathrm{mM} \mathrm{NaCl})$.

Guaiacol peroxidase: Control plants (T1) and plants treated only with brassinosteroid hormone (T2 and T3) did not record high GPX concentrations because did not present stress symptoms, although there were statistically significant differences between cultivars. The antioxidant system was efficient in cowpea subjected to saline stress treatments, as evidenced by the significant GPX increase in plants subjected to T4 and T5 (Figure 5D). BRS Guariba cultivar increased enzyme activity by $87 \%$ in T4 (with $50 \mathrm{mM} \mathrm{NaCl}$ ), whereas BR3 Tracuateua increased by $58 \%$, in comparison to the control. BRS Guariba increased GPX activity by $148 \%$ in T5 (with $100 \mathrm{mM} \mathrm{NaCl}$ ), whereas BR3 Tracuateua increased by $111 \%$. There were statistically significant differences in GPX concentrations between cultivars subjected to simultaneous salt and brassinosteroid doses (T6 to T9); Tracuateua cultivar was the most efficient one under saline stress conditions (Figure 5).

Malondialdehyde: Malondialdehyde (MDA) levels - a lipid peroxidation product - changed due to saline stress, as observed in $\mathrm{T} 4$ and $\mathrm{T5}$, which adopted $\mathrm{NaCl}$ concentrations $50 \mathrm{mM}$ and $100 \mathrm{mM}$, respectively. T4 and T5 recorded approximately two-fold MDA increase in comparison to the control.

However, treatments applying $\mathrm{NaCl}$ in association with brassinosteroid recorded reduced lipid peroxidation, with emphasis on $\mathrm{T} 6(0.2 \mu \mathrm{M} \mathrm{BR}+50 \mathrm{mM} \mathrm{NaCl})$ and T8 $(0.4 \mu \mathrm{M}$ $\mathrm{BR}+50 \mathrm{mM} \mathrm{NaCl})$. T4 and T5 showed statistically significant difference in MDA between cultivars at $5 \%$ probability level.

\section{Discussion}

According to Andrade Júnior et al. (2011), salinity affects water absorption due to the osmotic effect of $\mathrm{Na}^{+}$and $\mathrm{Cl}^{-}$, which reduces the water potential in the external solution. The excess of salt absorbed by plants leads to ionic imbalance, to damages to cytoplasm, as well as to injuries, mainly in edges, and at the apex, of leaves. Plants mainly lose water due to transpiration in these leaf regions, which, consequently, present accumulation of salts translocated from soil, as well as intense salt toxicity (Lima, 1997). Brassinosteroids have remarkable effects on resistance of plants subjected to saline stress. One of their most remarkable effects lies on increased plant resistance to different stress conditions (Zullo and Adam, 2002; Bajguaz and Tretyn, 2003) such as salt stress (Saíram, 1994; Anuradha and Rao, 2003). Assumingly, this hormone had direct influence on water retention because it is capable of controlling the aquaporin activity in the plasma membrane, thus enabling increased cell wall permeability and water molecule loosening, which resulted in cell expansion without losses on plasma membrane integrity (Morillon et al., 2001). According to Collado et al. (2010) and Zamani et al. (2010), high MDI values mainly reflect on composition, or structure, of lipids and proteins composing the plants, and this process increases ROS production in the structure of the membrane due to excess of $\mathrm{Na}^{+}$and $\mathrm{Cl}^{-}$ions.

High $\mathrm{Na}^{+}$ion absorption under salinity conditions can cause toxicity and prevent the absorption of essential nutrients, thus leading to ionic imbalance in the vegetables (Zhu, 2003). However, the effects of EBR attenuated the $\mathrm{Na}^{+}$ through the promotion of homeostasis of $\mathrm{K}^{+} / \mathrm{Na}^{+}$, which is reflected in a better activity of the root system and efficient antioxidant capacity of aerial part (Hu et al., 2016).

The increase in $\left(\mathrm{K}^{+}\right)$when applied the BR are due the high affinity transporters by $\mathrm{K}^{+}$(Ali et al., 2006), under salt conditions, these carriers have their activity blocked and, consequently, become an important path for absorption and inflow of the $\mathrm{Na}^{+}$(Amtmann and Sanders, 1998). Therefore, the Brazilian mitigate the negative effects of the $\mathrm{Na}^{+}$ion on cowpea plants.

According to Ashraf and Ahmad (2000), the toxic effect caused by the excess of $\mathrm{Na}^{+}$coming from the external environment can be mitigated through the following mechanisms: by restricting $\mathrm{Na}^{+}$input in cell through selective absorption; by excluding, or compartmentalizing, the excess of cytosolic $\mathrm{Na}^{+}$in vacuole; and by an efficient $\mathrm{Na}^{+}$partition system in plant.

According to Apse and Blumwald (2007), glycoproteins under normal conditions overall present high $\mathrm{K}^{+} / \mathrm{Na}^{+}$ratio approximately 10:20. Cowpea plants subjected to herein adopted salinity concentrations showed $\mathrm{K}^{+} / \mathrm{Na}^{+}$ratio values close to 1 . Therefore, several cellular processes, such as the ones involved in both enzyme activity and osmotic regulation, can be affected due to ion homeostasis breakdown (Ghars et al., 2008).

The increased potassium concentrations may be associated with fact that 24-EBL application reduced the Membrane Damage Index (MDI) and, consequently, it increased membrane selectivity. This outcome also enabled slight increase in $\mathrm{K}^{+} / \mathrm{Na}^{+}$ratio mainly due to physicochemical similarities between $\mathrm{Na}^{+}$and $\mathrm{K}^{+}$(Maathuis and Amtmann, 1999; Mässer et al., 2002). In fact, several evidences point towards the participation of high and low $\mathrm{K}^{+}$-affinity transporters in $\mathrm{Na}^{+}$transportation into cells, when it is found at high concentrations in soil (Blumwald, 2000); however, $\mathrm{Na}^{+}$concentrations decreased due to $24-\mathrm{EBL}$ action in the membrane.

The decreased sodium concentrations after 24-EBL application may have resulted from reduced $\mathrm{Na}^{+}$contents in cell tissues, from the possible dilution of toxic salts, since the hormone increased the water content in the leaves (RWC); or from increased accumulation, or synthesis, of compatible solutes in the plant, as reported in the current study.

According to Streit et al. (2005), plants enable cellular osmotic balance to help maintaining the water level in their leaves. In addition, some proteins involved in hydrophilic interaction with cellular macromolecules are synthesized in 


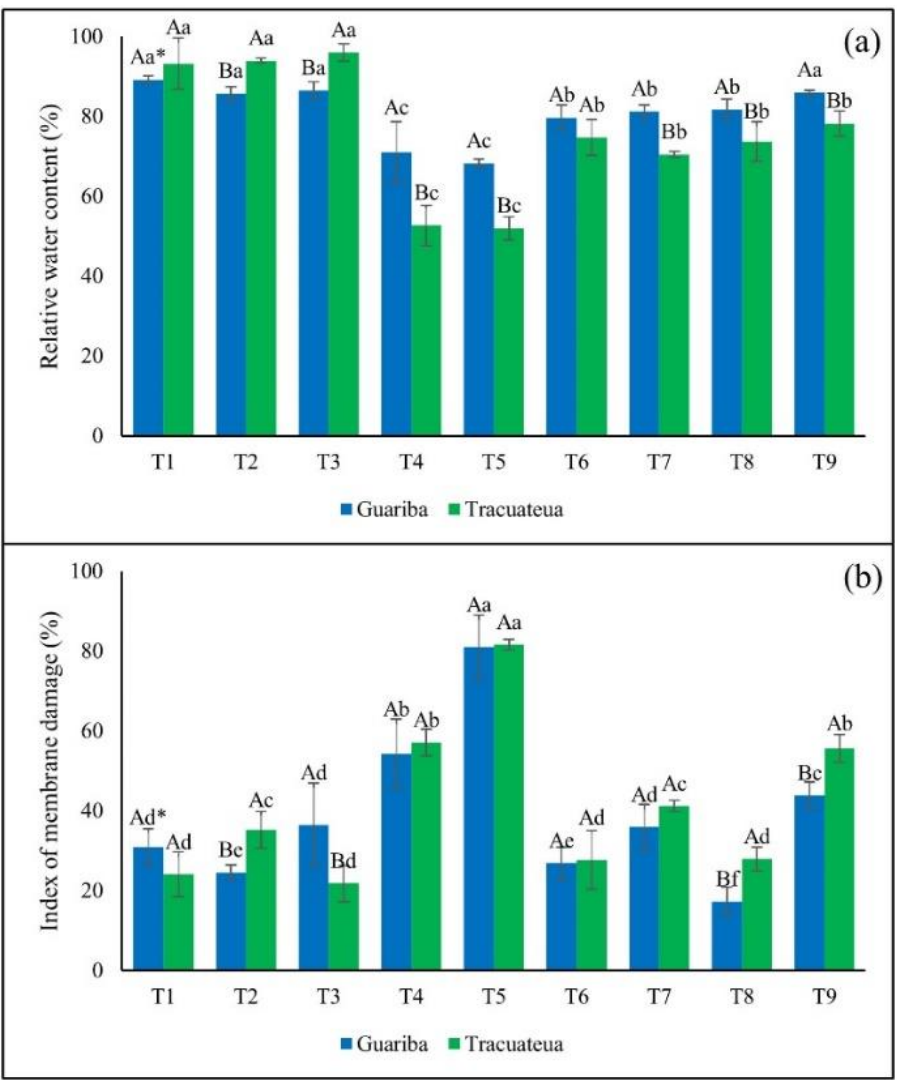

Fig 1. Relative water content (a) electrolyte leakage (b) based on treatments with $\mathrm{BR}(0.2$ and $0.4 \mu \mathrm{M})$ and $\mathrm{NaCl}(50$ and $100 \mathrm{mM})$. Legend: $\mathrm{T} 1=0 ; \mathrm{T} 2=0.2 \mu \mathrm{M} \mathrm{BR} ; \mathrm{T} 3=0.4 \mu \mathrm{M} \mathrm{BR} ; \mathrm{T} 4=50 \mathrm{mM} \mathrm{NaCl} T \mathrm{TS}=100 \mathrm{mM} \mathrm{NaCl} ; \mathrm{T}=0.2 \mu \mathrm{M} \mathrm{BR}+50 \mathrm{mM} \mathrm{NaCl} ; \mathrm{T7}=0.2 \mu \mathrm{M} \mathrm{BR}+100 \mathrm{mM} \mathrm{NaCl} ; \mathrm{T}=0.4 \mu \mathrm{M} \mathrm{BR}+50 \mathrm{mM} \mathrm{NaCl} ; \mathrm{Tg}=0.4 \mu \mathrm{M} \mathrm{BR}+$ $100 \mathrm{mM} \mathrm{NaCl}$. * Uppercase letters compare cowpea cultivars, whereas lowercase letters compare BR and NaCl rates in Scott-Knott test, at 5\% probability level.

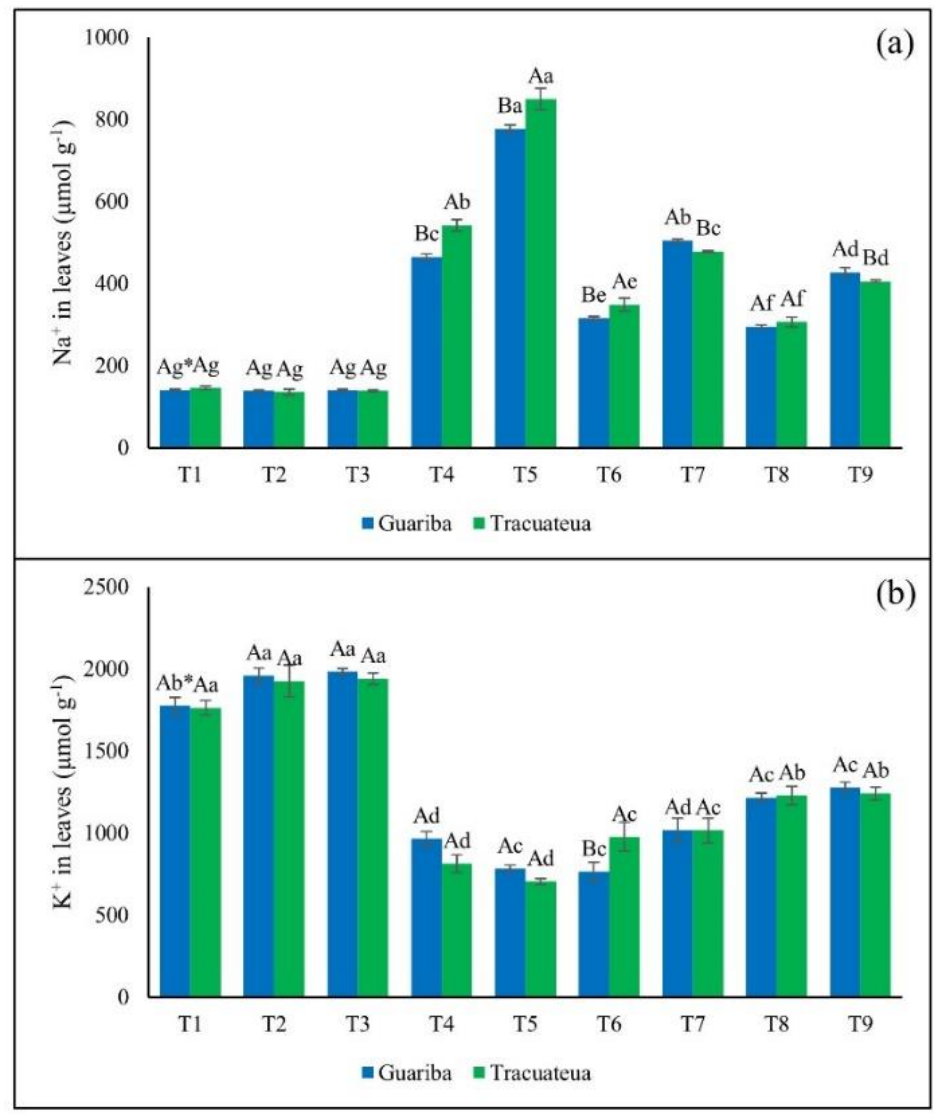

Fig 2. Sodium (a) and potassium concentration (b) based on treatments with $\mathrm{BR}(0.2$ and $0.4 \mu \mathrm{M})$ and $\mathrm{NaCl}(50$ and $100 \mathrm{mM})$. Legend: $\mathrm{T} 1=0 ; \mathrm{T} 2=0.2 \mu \mathrm{M} \mathrm{BR} ; \mathrm{T} 3=0.4 \mu \mathrm{M} \mathrm{BR} ; \mathrm{T} 4=50 \mathrm{mM} \mathrm{NaCl} ; \mathrm{T} 5=100 \mathrm{mM} \mathrm{NaCl} ; \mathrm{T} 6=0.2 \mu \mathrm{M} \mathrm{BR}+50 \mathrm{mM} \mathrm{NaCl} ; \mathrm{T} 7=0.2 \mu \mathrm{M}$ $\mathrm{BR}+100 \mathrm{mM} \mathrm{NaCl} ; \mathrm{T} 8=0.4 \mu \mathrm{M} \mathrm{BR}+50 \mathrm{mM} \mathrm{NaCl}$; T9 $=0.4 \mu \mathrm{M} \mathrm{BR}+100 \mathrm{mM} \mathrm{NaCl}$. * Uppercase letters compare cowpea cultivars, whereas lowercase letters compare BR and $\mathrm{NaCl}$ rates in Scott-Knott test, at $5 \%$ probability level. 


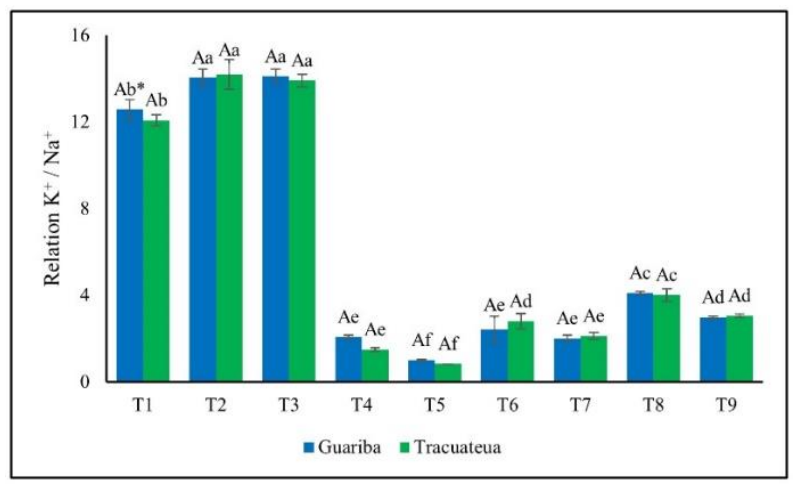

Fig 3. Relation the $\mathrm{K}^{+} / \mathrm{Na}^{+}$ratio based on treatments with $\mathrm{BR}(0.2$ and $0.4 \mu \mathrm{M})$ and $\mathrm{NaCl}(50$ and $100 \mathrm{mM})$. Legend: $\mathrm{T} 1=0 ; \mathrm{T} 2=0.2 \mu \mathrm{M} \mathrm{BR} ; \mathrm{T}=$ $0.4 \mu \mathrm{M} \mathrm{BR} ; \mathrm{T} 4=50 \mathrm{mM} \mathrm{NaCl}$ TS $=100 \mathrm{mM} \mathrm{NaCl} ; \mathrm{T}=0.2 \mu \mathrm{M} \mathrm{BR}+50 \mathrm{mM} \mathrm{NaCl} ; \mathrm{T} 7=0.2 \mu \mathrm{M} \mathrm{BR}+100 \mathrm{mM} \mathrm{NaCl} ; \mathrm{T}=0.4 \mu \mathrm{M} \mathrm{BR}+50 \mathrm{mM} \mathrm{NaCl} ; \mathrm{T} 9=0.4 \mu \mathrm{M} \mathrm{BR}+100 \mathrm{mM}$ NaCl. * Uppercase letters compare cowpea cultivars, whereas lowercase letters compare BR and NaCl rates in Scott-Knott test, at $5 \%$ probability level.

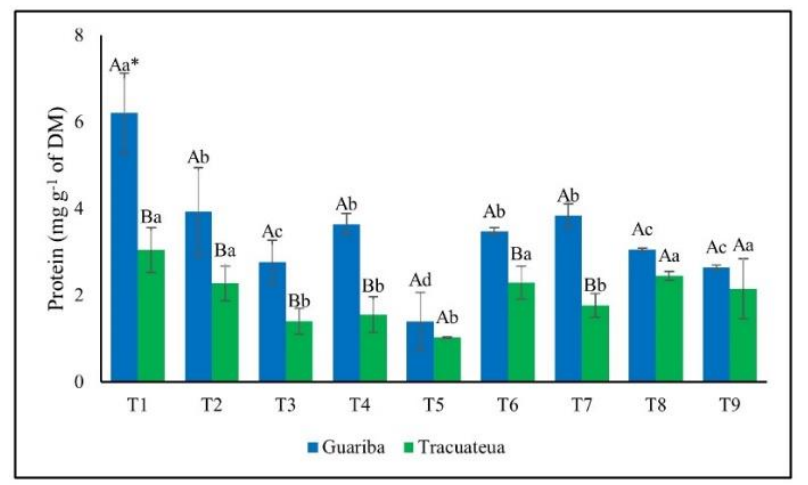

Fig 4. Total soluble protein content based on treatments with $\mathrm{BR}(0.2$ and $0.4 \mu \mathrm{M})$ and $\mathrm{NaCl}(50$ and $100 \mathrm{mM})$. Legend: $\mathrm{T} 1=0 ; \mathrm{T} 2=0.2 \mu \mathrm{M} \mathrm{BR}$; $\mathrm{T} 3=0.4 \mu \mathrm{M} \mathrm{BR} ; \mathrm{T} 4=50 \mathrm{mM} \mathrm{NaCl} ; \mathrm{TS}=100 \mathrm{mM} \mathrm{NaCl} ; \mathrm{T} 6=0.2 \mu \mathrm{M} \mathrm{BR}+50 \mathrm{mM} \mathrm{NaCl} ; \mathrm{T7}=0.2 \mu \mathrm{M} \mathrm{BR}+100 \mathrm{mM} \mathrm{NaCl} ; \mathrm{T} 8=0.4 \mu \mathrm{M} \mathrm{BR}+50 \mathrm{mM} \mathrm{NaCl} ; \mathrm{T}=0.4 \mu \mathrm{M} \mathrm{BR}+100 \mathrm{mM} \mathrm{NaCl}$.

* Uppercase letters compare cowpea cultivars, whereas lowercase letters compare BR and $\mathrm{NaCl}$ rates in Scott-Knott test, at $5 \%$ probability level.

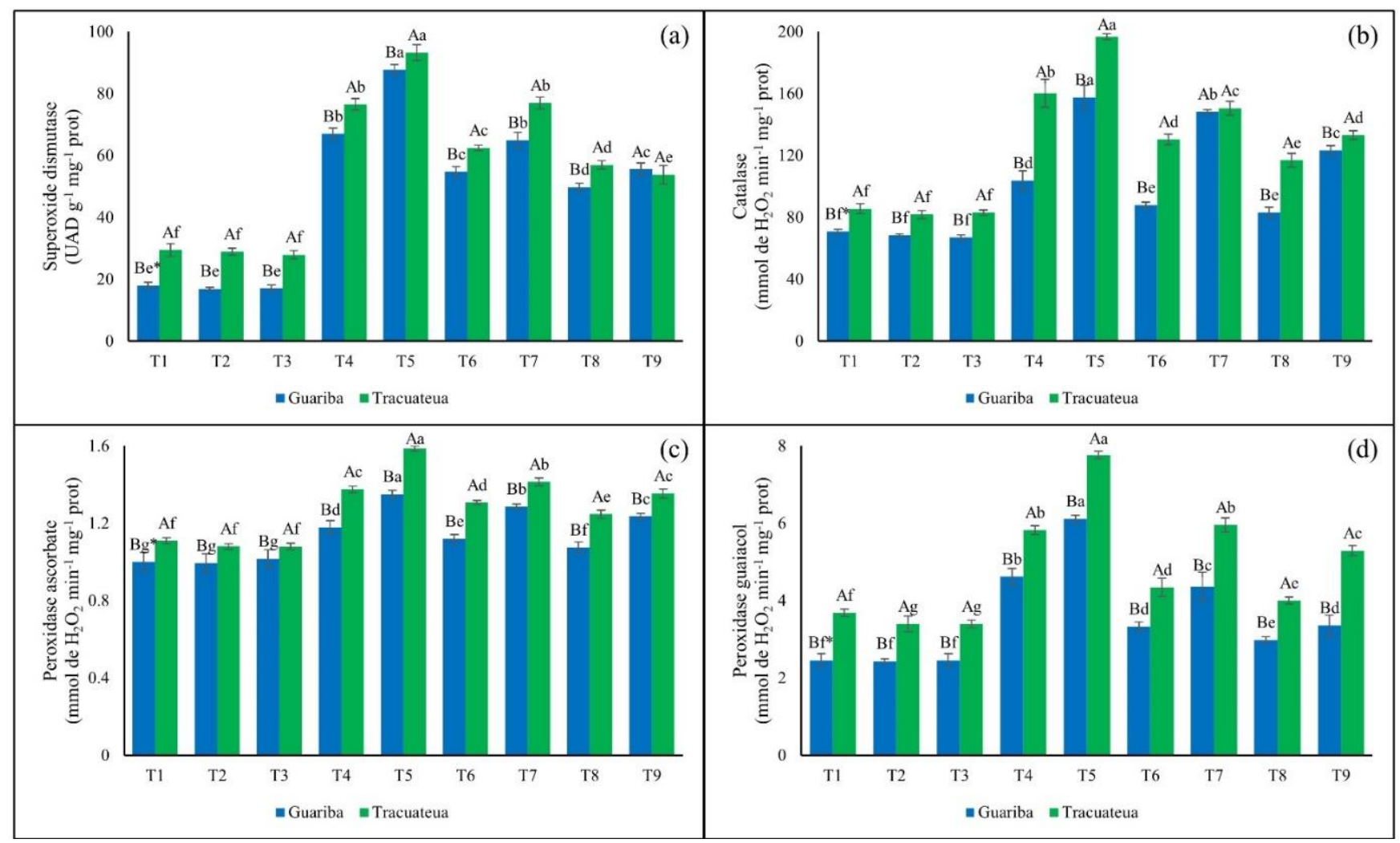

Fig 5. Superoxide dismutase (a), catalase (b), peroxidase ascorbate (c) and peroxidase guaiacol (d) enzyme activity based on treatments with BR $(0.2$ and $0.4 \mu \mathrm{M})$ and $\mathrm{NaCl}(50$ and $100 \mathrm{mM})$. Legend: $\mathrm{T} 1=0 ; \mathrm{T} 2=0.2 \mu \mathrm{M} \mathrm{BR} ; \mathrm{T} 3=0.4 \mu \mathrm{M} \mathrm{BR} ; \mathrm{T} 4=50 \mathrm{mM} \mathrm{NaCl} ; \mathrm{T5}=100 \mathrm{mM} \mathrm{NaCl} ; \mathrm{T} 6=0.2 \mu \mathrm{M}$ $\mathrm{BR}+50 \mathrm{mM} \mathrm{NaCl} ; \mathrm{T7}=0.2 \mu \mathrm{M} \mathrm{BR}+100 \mathrm{mM} \mathrm{NaCl} ; \mathrm{T} 8=0.4 \mu \mathrm{M} \mathrm{BR}+50 \mathrm{mM} \mathrm{NaCl} ; \mathrm{T} 9=0.4 \mu \mathrm{M} \mathrm{BR}+100 \mathrm{mM} \mathrm{NaCl}$. * Uppercase letters compare cowpea cultivars, whereas lowercase letters compare $\mathrm{BR}$ and $\mathrm{NaCl}$ rates in Scott-Knott test, at $5 \%$ probability level. 
order to enable plant metabolism and to help reversing damages caused by stress. Thus, it appears that the herein investigated hormone concentrations have enabled protein synthesis.Based on our results, it is possible saying that brassinosteroid concentrations were capable of reverting, although partially, the effects of salt stress, such as protein degradation or lower protein synthesis, as plants subjected to $\mathrm{NaCl}$ stress and supplemented with $0.2 \mathrm{Mm}$ of 24-EBL. Thus, brassinosteroid treatments were capable of partially reversing the effects of saline stress on plants by increasing protein concentrations in both cultivars. The brassine hormone in some cases tend to revert the effects of salinity, providing a relevant increase in some physiological processes, reflecting in high levels of this protein metabolite (Anuradha and Rao, 2001), as observed in this study. SOD is the first enzyme involved in plant defense system when the cell detects a stress signal and is responsible for the direct formation of different reactive oxygen species (Sankar et al., 2007). In response to SOD activity, the $\mathrm{H}_{2} \mathrm{O}_{2}$ level increases, thereby generating the action of secondary neutralizing enzymes such as CAT and peroxidases, APX and GPX, which are responsible for the dismutation of $\mathrm{H}_{2} \mathrm{O}_{2}$ in $\mathrm{H}_{2} \mathrm{O}+1 / 2 \mathrm{O}_{2}$ and $\mathrm{H}_{2} \mathrm{O}_{2}$ to $\mathrm{H}_{2} \mathrm{O}+\mathrm{R}(\mathrm{O})_{2}$, respectively. The action of these enzymes prevents further damage to cell membranes (Barbosa et al., 2014). The expressive response of CAT under conditions of saline stress observed in sensitive cultivar, this shows a possible phenotypic plasticity. One of advantages in operational aspect is that CAT performs its function independently of presence of reducing agents, with fast activity, approximately $10^{7} \mathrm{~min}^{-1}$, capable of neutralizing the $\mathrm{H}_{2} \mathrm{O}_{2}$ even before its diffusion through the cell (Akcay et al., 2010). APX is normally generated in plant cells during the biochemical stages within the organelles chloroplasts, mitochondria and peroxisomes, the main production sites (Voss et al., 2013), this information justifies the high concentrations of this enzyme in T1, T2 and T3 treatments, without plant stress. When subjected to saline stress the activity of enzyme increased trying to reduce the harmful effects of salinity (Abogadallah et al., 2010). And one of these attempts was to transform the $\mathrm{H}_{2} \mathrm{O}_{2}$ into $\mathrm{H}_{2} \mathrm{O}$. The remove ascorbate happens mainly in chloroplast and cytosol (Marti et al., 2009). The high GPX concentrations founded in plants under saline stress mainly influenced structures such as cell wall and vacuole to eliminate hydrogen peroxide $\mathrm{H}_{2} \mathrm{O}_{2}$ (Gill and Tuteja, 2010). Biochemically GPX acts by oxidizing a molecule of guaiacol and reducing four molecules of $\mathrm{H}_{2} \mathrm{O}_{2}$; by means of this reaction, a molecule of tetraguaiacol is formed with liberation of $\mathrm{H}_{2} \mathrm{O}$ (Fatibello-Filho and Vieira, 2002). MDA production resulting from lipid peroxidation has been used to indicate oxidative damages to plant tissues (Parida and Das, 2005). Some studies have shown increased MDA concentration, mainly in sensitive genotypes (Azevedo Neto et al., 2006; Farouk, 2011), and this outcome indicated the low protection of these cultivars against oxidative damages caused by saline stress.

\section{Materials and Methods}

\section{Plant material and growing conditions}

The experiment was carried out in greenhouse of Institute of Agricultural Sciences at Federal Rural University of Amazonia (UFRA), Belém city, Brazil. Biochemical and physiological analyses were carried out at Laboratory of Biodiversity Studies in Superior Plants (EBPS).
Two Vigna unguiculata (L.) Walp. cultivars were used in study: BRS Guariba and BR3 Tracuateua, which are classified as moderately tolerant and sensitive to saline stress (Cardoso et al., 2019), respectively, were provided from Germplasm Bank of Embrapa Eastern Amazon. Seedlings were placed in pots filled with $500 \mathrm{~mL}$ of sterilized and washed sand (two seedlings per pot) and nutrient solution, based on Hoagland and Arnon (1950).

Plant exposure to $\mathrm{NaCl}$ and brassinosteroids

The 24-epibrassinolide was dissolved in ethanol $\left(1 \mathrm{mg} \mathrm{mL}^{-1}\right)$ diluted in nutritive solution with $1 / 2$ ionic strength. Treatment with brassinosteroids, at concentrations $0,0.2$ and $0.4 \mu \mathrm{M}$, began at 10 DAS, when plants released the second pair of leaves. These conditions were kept for 7 days to enable plant acclimation. Next, plants were subjected to salt treatment at concentrations 0,50 and $100 \mathrm{mM}$ for 7 days.

Material collection and storage

Plant samples were collected at 24 DAS, at 04:30 a.m. Relative water content (RWC) was determined in vivo after fully-expanded primary leaves from each replicate were selected in greenhouse. Part of this material was used for electrolyte leakage (EL) determination purposes.

Subsequently, plant stems and leaves were separated from each other, wrapped in aluminum foil and stored in a freezer at $-80^{\circ} \mathrm{C}$ for oxidative stress analysis. The material was subjected to forced-air ventilation oven at $65^{\circ} \mathrm{C}$ for $48 \mathrm{~h}$ in order to enable total soluble protein analysis. Leaf dry mass was determined after the drying process was over. The dry material was milled into a fine powder and stored in falcon tubes to be used in future tests.

Biochemical variables

Relative water content was calculated based on Slavick (1974); Electrolyte leakage was analyzed based on the methodology adapted from Blum and Ebercon (1981); and Total Soluble Proteins was evaluated based on Bradford (1976); Membrane lipid peroxidation: test applied to thiobarbituric acid-reactive substances, based on the determination of malondialdehyde (MDA) levels, according to Cakmak and Horst (1991).

Antioxidant enzyme activity

Superoxide dismutase activity was determined based on method by Giannopolitis and Ries (1977); Catalase activity was determined based on Havir and McHale (1987); Ascorbate peroxidase activity was determined based on Nakano and Asada (1981); Guaiacol peroxidase activity was determined based on methodology described by Kar and Mishra (1976); $\mathrm{Na}^{+}$and $\mathrm{K}^{+}$concentrations were determined based on Viégas et al. (2001).

Experimental design and statistical analysis

The experimental design adopted was a completely randomized experimental design with $2 \times 3 \times 3$ factorial scheme, with 4 replicates. Experiments used 2 cowpea cultivars (BRS Guariba and BR3 Tracuateua), as well as 3 brassinosteroid $(0,0.2$ and $0.4 \mu \mathrm{M} \mathrm{Br})$ and $3 \mathrm{NaCl}(0,50$ and $100 \mathrm{mM} \mathrm{NaCl})$ concentrations. Data were subjected to analysis of variance (ANOVA) in Sisvar software version 5.4 (Ferreira, 2019), means were compared to each other in Scott-Knott test, at $5 \%$ probability level.

\section{Conclusion}

Based on our results, it was possible concluding that 24Epibrassinolide is efficient in enabling the acclimation of cowpea cultivars BRS Guariba and BR3 Tracuateua subjected to salt stress caused by $\mathrm{NaCl}$. 
Relative water content and electrolyte leakage were directly influenced by the action of 24-Epibrassinolide, as well as $\mathrm{Na}^{+}$ and $\mathrm{K}^{+}$concentrations, and $\mathrm{Na}^{+} / \mathrm{K}^{+}$ratio in leaves.

The use of 24-Epibrassinolide to activate the antioxidant system of plants proved to be effective, since plants subjected to different $\mathrm{NaCl}$ concentrations were able to maintain high antioxidant enzyme contents. In addition, 24Epibrassinolide reduced lipid peroxidation in membrane by improving the leaf cell wall in association with action of enzymes such as superoxide dismutase, catalase, ascorbate peroxidase, and guaiacol peroxidase.

\section{Acknowledgements}

The Federal Rural University of Amazonia for all structural support for the development of this work. To the National Council for Scientific and Technological Development (CNPq), for the financial support given to the conclusion of this work.

\section{Reference}

Abogadallah GM, Serag MM, Quick PW (2010) Fine and coarse regulation of reactive oxygen species in the salt tolerant mutants of barnyard grass and their wild-type parents under salt stress. Physiol Plantarum. 138:60-73.

Ahanger MA, Ashraf M, Bajguz A, Ahmad P (2018) Brassinosteroids regulate growth in plants under stressful environments and crosstalk with other potential phytohormons. J Plant Growth Regul. 37: 1007-1024.

Akcay UC, Ercan O, Kavas M, Yildiz L, Yilmaz C, Oktem HA, Yucel M (2010) Drought-induced oxidative damage and antioxidant responses in peanut (Arachis hypogaea L.) seedlings. Plant Growth Regul. 61: 21-28.

Ali B, Hayat S, Hasan SA, Ahmad A (2006) Effect of root applied 28homobrassinolide on the performance of Lycopersicon esculentum. Sci Hortic. 110: 267-273.

Amtmann A, Sanders D (1998) Mechanisms of $\mathrm{Na}^{+}$uptake by plant cells. Adv Bot Res. 29: 75-112.

Andrade Júnior WP, Pereira FHF, Fernandes OB, Queiroga RCF, Queiroga FM (2011) Effect of potassium nitrate on the reduction of saline stress on melon plant. Rev Caatinga. 24: 110-119.

Anuradha S, Rao SSR (2001) Effect of brassinosteroids on salinity stress induced inhibition of seed germination and seedling growth of rice (Oryza sativa L.). Plant Growth Regul. 33: 151-153.

Anuradha S, Rao SSR (2003) Application of brassinosteroids to rice seeds (Oryza sativa L.) reduced the impact of salt stress on growth, prevented photosynthetic pigment loss and increased nitrate reductase activity. Plant Growth Regul. 40: 29-32.

Apse MP, Blumwald E (2007) $\mathrm{Na}^{+}$transport in plants. FEBS Lett. 12: 2247-2254.

Ashraf M, Ahamad S (2000) Influence of sodium chloride on ion accumulation, yield components and fibre characteristics in salttolerant and salt-sensitive lines of cotton (Gossypium hirsutum L.). Field Crop Res. 66: 115-127.

Azevedo Neto AD, Prisco JT, Enéas Filho J, Abreu CEB, Gomes Filho E (2006) Effect of salt stress on antioxidative enzymes and lipid peroxidation in leaves and roots of salt-tolerant and salt-sensitive maize genotypes. Environ Exp Bot. 56: 87-94.

Bajguaz A, Tretyn A (2003) The chemical characteristic and distribution of brassinosteroids in plants. Phytochemistry. 62: 1027-1046.

Barbosa MR, Silva MMA, Willadino L, Ulisses C, Camara TR (2014) Plant generation and enzymatic detoxification of reactive oxygen species. Cienc Rural. 44: 453-460.

Blum A, Ebercon A (1981) Cell membrane stability as a measure of drought and heat tolerance in wheat. Crop Sci. 21: 43-47.

Blumwald E (2000) Sodium transport and salt tolerance in plants. Curr Opin Cell Biol. 12: 431-434.
Bradford MMA (1976) A rapid and sensitive method for the quantitation of microgram quantities of protein utilizing the principle of protein-dye binding. Anal Biochem. 72: 248-254.

Cakmak I, Horst JH (1991) Effects of aluminium on lipid peroxidation, superoxide dismutase, catalase, and peroxidase activities in root tips of soybean (Glycine max). Physiol Plantarum. 83: 463-468.

Cardoso KPS, Conceição SS, Brito AEA, Martins JTS, Machado LC, Costa TC, Nogueira GAS, Nascimento VR, Silva RPP, Paiva RC, Barbosa AVC, Okumura RS, Oliveira Neto CF (2019) Biochemical metabolism of two cultivars of cowpea treated with 24Epibrassinolide and subjected to saline stress. Aust J Crop Sci. 13: 444-451.

Cheng W, Huang $Y$, Meng C, Zhang N, Zeng H, Ren J, Li Y, Sun $Y$ (2015) Effect of exogenous 24-epibrassinolide on salt resistance of watermelon (Citrullus lanatus L.) under salinity stress. Paper presented at 5th International Conference on Advanced Design and Manufacturing Engineering (ICADME), Shenzen, China, 19-20 September 2015.

Coll Y, Coll F, Amorós A, Pujol M (2015) Brassinosteroids roles and applications: An up-date. Biologia. 70: 726-732.

Collado MB, Arturi MJ, Aulicino M, Molina MC (2010) Identification of salt tolerance in seedlings of maize (Zea mays L.) with the cell membrane stability trait. Int Res J Plant Sci. 5: 126-132.

Fariduddin Q, Yusuf M, Ahmad I, Ahmad A (2014) Brassinosteroids and their role in response of plants to abiotic stresses. Biol Plantarum. 58: 9-17.

Farouk S (2011) Ascorbic acid and $\alpha$-tocopherol minimize saltinduced wheat leaf senescence. J Stress Physiol Biochem. 7: 5879.

Fatibello-Filho O, Vieira IC (2002) Analytical use of vegetal tissue and crude extract as enzymatic source. Quím Nova. 25: 455-464.

Ferreira DF (2019) Sisvar: A computer analysis system to fixed effects split plot type designs. Rev Bras Biom. 37: 529-535.

Ghars MA, Parre E, Debez A, Bordenave M, Richard L, Leport L, Bouchereau A, Savouré A, Abdelly C (2008) Comparative salt tolerance analysis between Arabidopsis thaliana and Thellungiella halophyla, with special emphasis on $\mathrm{K}^{+} / \mathrm{Na}^{+}$selectivity and proline accumulation. J Plant Physiol. 165: 588-599.

Giannopolitis CN, Ries SK (1977) Superoxide dismutases. I. Occurrence in higher plants. Plant Physiol. 59: 309-314.

Gill SS, Tuteja N (2010) Reactive oxygen species and antioxidant machinery in abiotic stress tolerance in crop plants. Plant Physiol Bioch. 48: 909-930.

Gonçalves KS, Sousa AP, Veline ED (2015) Application of plant growth regulators and potassium phosphite on eucalyptus seedlings under water stress. Irriga. 20: 273-285.

Havir E, McHale NA (1987) Biochemical and developmental characterization of multiple forms of catalases in tobacco leaves. Plant Physiol. 84: 450-455.

Hoagland DR, Arnon DI (1950) The water-culture method for growing plants without soil. Berkeley, Calif Agric Exp Sta. 32p.

Hu Y, Xia S, Su Y, Wang H, Luo W, Su S, Xiao L (2016) Brassinolide increases potato root growth in vitro in a dose-dependent way and alleviates salinity stress. BioMed Res Int. 2016: 1-11.

Kar M, Mishra D (1976) Catalase, peroxidase, and polyphenoloxidase activities during rice leaf senescence. Plant Physiol.57: 315-319.

Lima LA (1997) Efeitos dos sais no solo e na planta. In: Ghiyi HR, Queroz JE, Medeiros JF (eds) Manejo e controle da salinidade na agricultura irrigada. Campina Grande, UFPB. p.113-136.

Maathuis FJM, Amtmann AK (1999) $\mathrm{K}^{+}$nutrition and $\mathrm{Na}^{+}$toxicity: The basis of cellular $\mathrm{K}^{+} / \mathrm{Na}^{+}$ratios. Ann Bot. 84: 123-133.

Maia JM, Macedo CEC, Voigt EL, Freitas JBS, Silveira JAG (2010) Antioxidative enzymatic protection in leaves of two constrasting cowpea cultivars under salinity. Biol Plantarum. 54: 159-163.

Martí CM, Camejo D, Garcia-Fernandez N, Alverez-Rellan R, Marques $S$, Sevilla F, Jimenez A (2009) Effect of oil refinery sludges on the growth and antioxidant system of alfalfa plants. J Hazard Mater. 171: 879-885.

Mässer P, Gierth M, Schroeder J (2002) Molecular mechanism of potassium and sodium uptake in plants. Plant Soil. 247: 43-54.

Medeiros R, Valdinar S, Araújo A, Oliveira Filho C (2008) Saline stress on nodulation of cowpea. Rev Caatinga. 21: 202-206 
Morillon R, Catterou M, Sangwan RS, Sangwan BS, Lassalles JP (2001) Brassinolide may control aquaporin activies in Arabidopsis thaliana. Planta. 212: 199-204.

Munns R, Gilliham M (2015) Salinity tolerance of crops - what is the cost?. New Phytol. 208: 668-673.

Nakano Y, Asada K (1981) Hydrogen peroxide is scavenged by ascorbate-specific peroxidases in spinach chloroplasts. Plant Cell Physiol. 22: 867-880.

Parida AK, Das AB (2005) Salt tolerance and salinity effects on plants: A review. Ecotox Environ Safe. 60: 324-349.

Parvaiz A, Satyawati S (2008) Salt stress and phyto-biochemical responses of plants - A review. Plant Soil Environ. 54: 89-99.

Qin J, Dong WY, He KN, Yu Y, Tan GD, Han L, Dong M, Zhang YY, Zhang D, Li Z A, Wang ZL (2010) NaCl salinity-induced changes in water status, ion contents and photosynthetic properties of Shepherdia argentea (Pursh) Nutt. seedlings. Plant Soil Environ. 56: 325-332.

Saíram RK (1994) Effects of homobrassinolide application on metabolic activity and grain yield of wheat under normal and water-stress condition. J Agron Crop Sci. 173: 11-16.

Sankar B, Jaleel CA, Manivannan P, Kishorekumar A, Somasundaram $R$, Panneerselvam R (2007) Effect of paclobutrazol on water stress amelioration through antioxidants and free radical scavenging enzymes in Arachis hypogaea L. Colloid Surface B. 60: 229-235.

Santos HRB (2015) Abordagem multivariada de características fisiológicas foliares de cana-de-açúcar sob estresse hídrico. Tese, Universidade Federal de Lavras. 70p.

Sharma P, Bhardwaj R, Arora N, Arora HK (2007) Effect of 28homobrassinolide on growth, zinc metal uptake and antioxidative enzyme activities in Brassica juncea L. seedlings. Braz J Plant Physiol. 19: 203-207.
Slavick B (1974) Methods of studying plant water relations. New York, Springer Verlang. 449p.

Streit NM, Canterle LP, Canto MW, Hecktheuer LHH (2005) The chlorophylls. Cienc Rural. 35: 748-755.

Toppa EVB, Brambilla WP (2011) The plant breeding and soil salinity. Rev Verde Agroecologia Desenvolv Sustent. 6: 21-25

Vázques MN, Guerrero YR, Noval WT, González LM, Zullo MAT (2019) Advances on exogenous applications of brassinosteroids and their analogs to enhance plant tolerance to salinity: A review. Aust J Crop Sci. 13: 115-121.

Viégas RA, Silveira JAG, Junior ARL, Queiroz JE, Fausto MJM (2001) Effects of $\mathrm{NaCl}$-salinity on growth and inorganic solute accumulation in Young cashew plants. Rev Bras Eng Agríc Ambient. 5: 216-222.

Voss I, Sunil B, Scheibe R, Raghavendra AS (2013) Emerging concept for the role of photorespiration as an important part of abiotic stress response. Plant Biology. 15: 713-722.

Wang D, Li YH, Xu NJ, Xu XT (2016) Combined effects of 24epibrassinolide and salinity on the growth and physiological performance of Ulva prolifera. J Appl Ecol. 27: 946-952.

Yildirim E, Karlidag H, Turan M (2009) Mitigation of salt stress in strawberry by foliar $\mathrm{K}, \mathrm{Ca}$ and $\mathrm{Mg}$ nutrient supply. Plant Soil Environ. 55: 213-221.

Zamani S, Bybordi A, Khorshidi S, Nezami T (2010) Effects of $\mathrm{NaCl}$ salinity level on lipids and proteins of canola (Brassica napus L.) cultivars. Adv Environ Biol. 4: 397-403.

Zhu JK (2003) Regulation of ion homeostasis under salt stress. Curr Opin Plant Biol. 6: 441-445.

Zullo AT, Adam G (2002) Brassinosteroid phytohormones - structure, bioactivity and applications. Braz J Plant Physiol. 14: 143-181. 